\title{
Tissue-specific responses of oxidative stress biomarkers and antioxidant defenses in rainbow trout Oncorhynchus mykiss during a vaccination against furunculosis
}

\author{
Halyna Tkachenko • Natalia Kurhaluk • \\ Joanna Grudniewska • Anastasiia Andriichuk
}

Received: 12 July 2013/Accepted: 21 February 2014/Published online: 6 March 2014

(C) The Author(s) 2014. This article is published with open access at Springerlink.com

\begin{abstract}
The present study was conducted to evaluate the effects of vaccination against furunculosis on responses of oxidative stress and antioxidant defenses in rainbow trout Oncorhynchus mykiss muscle, gills, liver, and brain tissues. The oxidative stress markers (malondialdehyde and carbonyl derivatives of protein oxidative destruction levels), antioxidant defenses (superoxide dismutase, catalase, glutathione reductase, and glutathione peroxidase), and total antioxidant capacity in different tissues of rainbow trout were measured. Our data showed that exposure of trout to vaccine against furunculosis produced changes (either increase or decrease) in oxidative stress and antioxidant enzymes responses, and these responses showed marked organ differences, associated with tissue patterns. Our study demonstrated that vaccinated trout showed alteration in antioxidant defenses and oxidative stress responses, with higher severity in the liver,
\end{abstract}

H. Tkachenko · N. Kurhaluk ( $\square) \cdot$ A. Andriichuk Department of Zoology and Animal Physiology, Institute of Biology and Environmental Protection, Pomeranian University, Slupsk, Poland e-mail: kurhaluk@apsl.edu.pl

H. Tkachenko

e-mail: tkachenko@apsl.edu.pl

J. Grudniewska

Department of Salmonid Research, Inland Fisheries

Institute, Rutki, 83-330 Żukowo, Poland

e-mail: jgrudniewska@infish.com.pl compared with other tissues. Our data also suggest that vaccination against furunculosis induced lipid peroxidation in gill and liver tissues. However, muscle and brain tissue are capable of restoring its pro- and antioxidant balance after vaccination.

Keywords Lipid peroxidation · Oxidatively modified proteins - Antioxidant enzymes · Muscle · Gills · Liver · Brain · Rainbow trout Oncorhynchus mykiss

\section{Introduction}

Salmonids are an important species for pond aquaculture and extensive open water fisheries in several European countries. In Poland, the intensification of salmonids production is occurring, especially in water recirculation systems. Rapid growth and disease resistance are the most important concerns in the present aquaculture industry (Andrews et al. 2011).

The most important bacterial fish diseases in European freshwater aquaculture are the rainbow trout fry syndrome (Flavobacterium psychrophilum) and enteric redmouth disease (Yersinia ruckeri) that are widespread and cause serious epizootics, while furunculosis (Aeromonas salmonicida) is endemic, only giving overt disease under extremely stressing conditions (Larsen and Pedersen 1997). Salmonids are vulnerable to furunculosis, a disease caused by the 
Gram-negative bacterium Aeromonas salmonicida and Aeromonas hydrophila (Vanya Ewart et al. 2008; Swain et al. 2010). Infections with A. salmonicida and A. hydrophila are probably the most important disease problems in European aquaculture as they are widespread and cause disease both in fresh water and sea water (Press and Lillehaug 1995). The term furunculosis is derived from the characteristic furuncles in muscles, which are common during a chronic course of the disease. Otherwise, the dominant pathological findings are a swollen, dark spleen, and petechial hemorrhages in internal organs (Press and Lillehaug 1995).

Increased incidence of infectious diseases connected with Aeromonas infection has traditionally been treated with antibiotics, chemotherapeutics, and vaccines (Harikrishnan et al. 2010). The use of immunostimulants in fish for the modulation of nonspecific defense mechanisms and protection against infectious diseases is a promising new development (Siwicki et al. 1994, 1998; Bricknell and Dalmo 2005). So vaccination is the most promising concept to control disease (Swain et al. 2010). Vaccination against furunculosis reduces mortality of salmonids but fails to eradicate infection. Efficiency of vaccination depends largely on the ability of host to neutralize the negative impacts of immune responses combined with efficient clearance and prevention of tissue damages (Skugor et al. 2009). Since the introduction of successful oil-adjuvanted vaccines in the early 1990s, a number of studies have been published on the protective as well as adverse effects of these vaccines (Rømer Villumsen et al. 2012).

Different kinds of vaccines have been investigated against A. hydrophila including whole cell, outer membrane proteins, extra-cellular proteins, lipopolysaccharides, and biofilms-attenuated vaccines (Loghothetis and Austin 1994; Karunasagar et al. 1997; Siwicki et al. 1998; Rahman and Kawai 2000; Azad et al. 2000; Vivas et al. 2004). While each medicine probably are effective in the treatment of a particular disease, problems arise with the development of possible pathological side effects of immunization in fishes, as well as the emergence of antibiotic resistant pathogenic strains. For optimal protection of salmonids in seawater, vaccination should be carried out sometime before sea transfer, in order to give immunity sufficient time to develop, and to avoid handling stress during smoltification. On the other hand, however, vaccination should not be carried out too early, as the degree of immunity declines with time (Sommerset et al. 2005). Water temperature is an important factor when deciding when to vaccinate (Lillehaug 1997). Results of Skugor et al. (2009) suggest that outcomes of vaccination depend largely on the ability of host to prevent the negative impacts of immune responses and to repair damages. This can be illustrated with the inductions of protease inhibitors, negative regulators of complement, and genes involved in metabolism of lipids and xenobiotics and growth factors. There was no strong association between survival and most anti-bacterial responses though vaccinated fish with high resistance to furunculosis (Skugor et al. 2009).

Despite the importance and success of vaccination, little is known about the mechanisms of oxidative stress and antioxidant defenses in fish during vaccination. In the present study, we determined the influence of vaccination against furunculosis on tissue-specific responses of oxidative stress biomarkers and antioxidant defense in rainbow trout, Oncorhynchus mykiss. In the present work, a comparative study is made concerning the oxidative stress biomarkers (lipid peroxidation and oxidatively modified protein levels), as well as activities of the antioxidant enzymes (superoxide dismutase, catalase, glutathione reductase, and glutathione peroxidase) and total antioxidant capacity in white muscle, gills, liver, and brain tissues of the rainbow trout $O$. mykiss treated by vaccine against furunculosis.

\section{Materials and methods}

\section{Experimental animals}

Clinically healthy rainbow trout (Oncorhynchus mykiss Walbaum) with a mean body mass of $135.5 \pm 1.5 \mathrm{~g}$ were used in the experiments. The study was carried out in a Department of Salmonid Research, Inland Fisheries Institute near the village of Żukowo (Poland). The experiments were conducted with the current laws in Poland, according to the guidelines of Local Ethical Commission.

Experiments were performed at a water temperature of $14.5 \pm 0.5^{\circ} \mathrm{C}$, and the $\mathrm{pH}$ was 7.5 . The dissolved oxygen level was about $12 \mathrm{ppm}$ with additional oxygen supply with a water flow of 25 
$\mathrm{L} / \mathrm{min}$ and a photoperiod of $7 \mathrm{~h}$ per day. The fish were fed with commercial pelleted diet. All enzymatic assays were carried out at Department of Animal Physiology, Institute of Biology and Environmental Protection, Pomeranian University (Słupsk, Poland).

\section{Experimental design}

The fish were divided into two groups: (1) unhandled control, (2) vaccinated by vaccine against furunculosis. Fish were held in 250-L square tanks (70-75 fish per tank) with the same conditions. Before vaccination, the fish were anaesthetized by Propiscin solution (Siwicki et al. 2002). The vaccine against furunculosis is a vaccine containing an inactivated strain of $A$. salmonicida and $A$. hydrophila in concentration $1 \times 10^{10}$ colony-forming units (CFU). The vaccine was produced in Department of Epizootology, Faculty of Veterinary Medicine, University of Warmia and Mazury (Olsztyn, Poland). Immersion contained 1 liter of vaccine per $10 \mathrm{~L}$ of water. It was prepared immediately prior to vaccination. Immersion lasted from 60 to $120 \mathrm{~s}$. The fish were kept for 30 days at $14.5^{\circ} \mathrm{C}$ after vaccination at a water temperature of $14.5 \pm 0.5^{\circ} \mathrm{C}$ and the $\mathrm{pH}$ 7.5. In our study, 15 rainbow trout from unhandled control and 15 vaccinated trout were used.

\section{Sampling}

The animals were quickly captured and killed on 31 days post vaccination ( $n=15$ in each group). White muscle, gills, liver, and brain tissues were removed in situ. Tissue samples were homogenized in ice-cold buffer (100 mM Tris-HCl, pH 7.2) using a glass homogenizer immersed in an ice-water bath to a yield a $10 \%$ homogenate. Homogenates were centrifuged at $3,000 \mathrm{~g}$ for $15 \mathrm{~min}$ at $4{ }^{\circ} \mathrm{C}$. After centrifugation, the supernatant was collected and frozen at $-20{ }^{\circ} \mathrm{C}$ until analyzed. Protein contents were determined using the method of Bradford (1976) with bovine serum albumin as a standard. Absorbance was recorded at $595 \mathrm{~nm}$. All enzymatic assays were carried out at $22 \pm 0.5{ }^{\circ} \mathrm{C}$ using a Specol 11 spectrophotometer (Carl Zeiss Jena, Germany) in duplicate. The enzymatic reactions were started by the addition of the tissue supernatant. The specific assay conditions were as follows.
Oxidative stress biomarkers assay

Assay of thiobarbituric acid reactive substances (TBARS) levels

An aliquot of the homogenate was used to determine the lipid peroxidation status of the sample by measuring the concentration of thiobarbituric acid-reacting substances (TBARS), according to the method of Kamyshnikov (2004). Reaction mixture contains sample homogenate $(2.1 \mathrm{~mL}, 10 \% \mathrm{w} / \mathrm{v})$ in Tris- $\mathrm{HCl}$ buffer (100 mM, pH 7.2), 2-thiobarbituric acid (TBA; $0.8 \%, 1.0 \mathrm{~mL}$ ), and trichloracetic acid (TCA; $20 \%$, $1.0 \mathrm{~mL}$ ). The total volume was kept in a water bath at $100{ }^{\circ} \mathrm{C}$ for $10 \mathrm{~min}$. After cooling, mixture was centrifuged at $3,000 \mathrm{~g}$ for $10 \mathrm{~min}$. The absorbance of the supernatant was measured at $540 \mathrm{~nm}$. TBARS values were reported as nmoles malondialdehyde (MDA) per mg protein.

\section{Assay of carbonyl groups of oxidatively modified protein levels}

Carbonyl groups were measured as an indication of oxidative damage to proteins according to the method of Levine et al. (1990) in modification of Dubinina et al. (1995). Samples were incubated at room temperature for $1 \mathrm{~h}$ with $10 \mathrm{mM}$ 2,4-dinitrophenylhydrazine (DNTP) in $2 \mathrm{M} \mathrm{HCl}$. Blanks were run without DNTP. Afterward, proteins were precipitated with TCA and centrifuged for $20 \mathrm{~min}$ at $3,000 \mathrm{~g}$. The protein pellet was washed three times with ethanol/ ethylacetate $(1: 1)$ and incubated at $37{ }^{\circ} \mathrm{C}$ until complete resuspension. The carbonyl content could be measured spectrophotometrically at $370 \mathrm{~nm}$ (aldehyde derivates, $\mathrm{OMP}_{370}$ ) and at $430 \mathrm{~nm}$ (ketonic derivates, $\mathrm{OMP}_{430}$ ) (molar extinction coefficient $22,000 \mathrm{M}^{-1} \mathrm{~cm}^{-1}$ ) and expressed as nmol per $\mathrm{mg}$ protein.

\section{Assay of superoxide dismutase activity}

Superoxide dismutase (SOD, E.C. 1.15.1.1) activity in supernatant was determined according to the Kostiuk et al. (1990). SOD activity was assessed by its ability to dismutate superoxide produced during quercetin auto-oxidation in an alkaline medium ( $\mathrm{pH} 10.0)$. Briefly, $1.0 \mathrm{~mL}$ of $\mathrm{C}$ reagent was mixed with $0.1 \mathrm{~mL}$ homogenate $(1: 1,000)$. C reagent was made ex 
tempore (mixture of equal volumes of $0.1 \mathrm{M} \mathrm{K}, \mathrm{Na}$ phosphate buffer, $\mathrm{pH} 7.8$, and 0.08 M EDTA); $\mathrm{pH}$ of $\mathrm{C}$ reagent was adjusted to 10.0 by adding tetramethylenediamine. Distilled water $(0.1 \mathrm{~mL})$ was added to blank instead of homogenate. The total volume was then made up to $2.4 \mathrm{~mL}$ with distilled water. The reaction was initiated by adding $0.1 \mathrm{~mL}$ of quercetin $(1.4 \mu \mathrm{M})$. Absorbance at $406 \mathrm{~nm}$ was measured immediately and after $20 \mathrm{~min}$. Activity is expressed in units of SOD per mg of tissue protein.

\section{Assay of catalase activity}

Catalase (CAT; EC 1.11.1.6) activity was determined by measuring the decrease in $\mathrm{H}_{2} \mathrm{O}_{2}$ concentration at $410 \mathrm{~nm}$ according to Koroliuk et al. (1988). The rate of decrease in $\mathrm{H}_{2} \mathrm{O}_{2}$ content is directly proportional to the CAT activity in the sample. Assays were performed in a reaction mixture containing $2 \mathrm{~mL}$ of $0.03 \% \mathrm{H}_{2} \mathrm{O}_{2}$ solution and $0.1 \mathrm{~mL}$ of tissue homogenate. The duration of this reaction was $10 \mathrm{~min}$ at room temperature. The reaction was terminated by rapid adding of $1.0 \mathrm{~mL}$ of $4 \%$ ammonium molybdate dissolved in $12.5 \mathrm{mM} \mathrm{H}_{2} \mathrm{SO}_{4}$ and $1 \mathrm{~mL}$ of $125 \mathrm{mM}$ $\mathrm{H}_{2} \mathrm{SO}_{4}$. All samples were centrifuged at $3,000 \mathrm{~g}$ for $10 \mathrm{~min}$. One unit of CAT activity was defined as the decrease of $1 \mu \mathrm{mol}$ in $\mathrm{H}_{2} \mathrm{O}_{2}$ per minute. CAT activities were expressed as one unit per milligram protein.

\section{Assay of glutathione reductase activity}

Glutathione reductase (GR, EC 1.6.4.2) activity was assayed as described by Glatzle et al. (1974) with some modifications. The enzymatic activity was assayed spectrophotometrically by measuring NADPH consumption. In the presence of GSSG and NADPH, GR reduces GSSG and oxidizes NADPH, resulting in a decrease in absorbance at $340 \mathrm{~nm}$. Quantification was based on the molar extinction coefficient of $6.22 \mathrm{mM}^{-1} \mathrm{~cm}^{-1}$ of NADPH. One unit of GR was defined as the amount of enzyme that reduced $1 \mu \mathrm{mol}$ of NADPH with GSSG per minute. The GR activities were expressed as one unit per mg protein.

\section{Assay of glutathione peroxidase activity}

Glutathione peroxidase (GPx, EC 1.11.1.9) activities were determined on the detection of nonenzymatic utilization of GSH as the reacting substrate at an absorbance of $412 \mathrm{~nm}$ after incubation with 5,5dithiobis-2-nitrobenzoic acid (DTNB) according to the method of Moin (1986). Briefly, reaction mixture contained $0.8 \mathrm{~mL}$ of $0.1 \mathrm{M}$ Tris-HCl buffer ( $\mathrm{pH} 8.9$ ) with $12 \mathrm{mM}$ sodium azide, $6 \mathrm{mM}$ EDTA, $0.2 \mathrm{~mL}$ of homogenate, $0.1 \mathrm{~mL}$ of $4.8 \mathrm{mM}$ glutathione, and $0.1 \mathrm{~mL}$ of $20 \mathrm{mM}$ t-butyl hydroperoxide. The contents were incubated at $37{ }^{\circ} \mathrm{C}$ for $10 \mathrm{~min}$. The reaction was arrested by $0.2 \mathrm{~mL}$ of $20 \%$ TCA and centrifuged. Supernatant was assayed for glutathione content using Ellman's reagent (39.6 mg of DTNB in $10 \mathrm{~mL}$ of $1 \%$ sodium citrate). A unit of enzyme activity is defined as the amount of enzyme catalyzing the formation of $1 \mu \mathrm{M}$ of GSH per min, and the activity of GPx was calculated based on tissue protein concentration.

\section{Assay of total antioxidant capacity (TAC)}

The TAC level was estimated spectrophotometrically at $532 \mathrm{~nm}$ following the method with Tween 80 oxidation (Galaktionova et al. 1998). Briefly, $0.2 \mathrm{~mL}$ of tissue homogenate was added to $2 \mathrm{~mL}$ of $1 \%$ Tween 80. Blank assay instead of sample included $0.1 \mathrm{~mL}$ of distilled water. The mixture was incubated during $48 \mathrm{~h}$ at $37{ }^{\circ} \mathrm{C}$. After cooling, $1 \mathrm{~mL}$ of $40 \%$ TCA was added. The mixture was centrifuged at $3,000 \mathrm{~g}$ for $10 \mathrm{~min}$. After centrifugation, $2 \mathrm{~mL}$ of supernatant and $2 \mathrm{~mL}$ of $0.25 \%$ TBA reagent were mixed. The mixture was heated in boiling water bath at $100{ }^{\circ} \mathrm{C}$ for $15 \mathrm{~min}$. The absorbance of the obtained solution was measured at $532 \mathrm{~nm}$ and was compared with the blank. TAC level was expressed in $\%$.

\section{Statistical analysis}

Data were presented as the mean \pm SEM and were checked for assumptions of normality using the Kolmogorov-Smirnov one-sample test and Lilliefors test $(p>0.05)$. Homogeneity of variance was checked using the Levene's test. One-way analysis of variance (ANOVA) was used to check for differences between the control and vaccinated groups. Significance of differences in the lipid peroxidation level, level of carbonyl derivatives of amino acids reaction, and antioxidant enzymes activities was examined using Mann-Whitney $U$ test according to Zar (1999). Differences were considered significant at $p<0.05$. 
All statistical analysis was performed by STATISTICA 8.0 software (StatSoft, Poland).

\section{Results}

The level of lipid peroxidation in the muscle tissue of trout treated by vaccine did not significantly differ from that in the controls (Fig. 1). The gill and hepar tissues of vaccinated trout demonstrated significantly higher TBARS levels (3.82- and 6.25-fold, $p=0.000$, respectively) compared with unhandled control fish (Fig. 1). Vaccination caused a significant decrease in the TBARS level of the brain tissue by $24 \%$ $(p=0.017)$.

Aldehyde and ketonic derivates of carbonyl content in the trout vaccinated against furunculosis were significantly reduced in the muscle (by $57 \%$ and by $47.5 \%, p=0.000$, respectively), gills (by $65 \%$ and by $59 \%, p=0.000$, respectively), and brain tissue (by $27 \%, p=0.008$ and by $24 \%, p=0.006$, respectively) compared with the level in the control (Fig. 2). In contrast, significantly increased carbonyl content was measured in the liver of fish exposed to vaccine in comparison with the control values (6.2and 5.8-fold for aldehyde and ketonic derivates, respectively) (Fig. 2).
The activities of antioxidant enzymes in the muscle, gill, liver, and brain tissues in response to vaccine treatment are presented in Table 1. No significant change in SOD activity in the gills and brain tissue was observed for vaccinated group compared with the control activities level. Muscle and liver SOD activity was significantly higher than that in the control (3.5and 2.1-fold, respectively). CAT, GR, and GPx activities in the muscle and gill were also significantly inhibited in vaccinated fish. In contrary, hepatic CAT, GR, and GPx activities were significantly increased compared with the control activities (Table 1).

The total antioxidant capacity (Fig. 3) was significantly decreased in all tissues compared with those in the control (in muscle by $43 \%, p=0.002$, in gills by $42 \%, p=0.012$, in liver by $50 \%, p=0.006$, and in brain by $43 \%, p=0.000$ ).

\section{Discussion}

The study shows a post-treatment change in oxidative stress profile in the muscle, gills, liver, and brain of rainbow trout treated by vaccine against furunculosis. Our study showed that treatment with vaccine resulted in significant reduction in lipid peroxidation biomarker level in brain tissue. The decrease in aldehyde

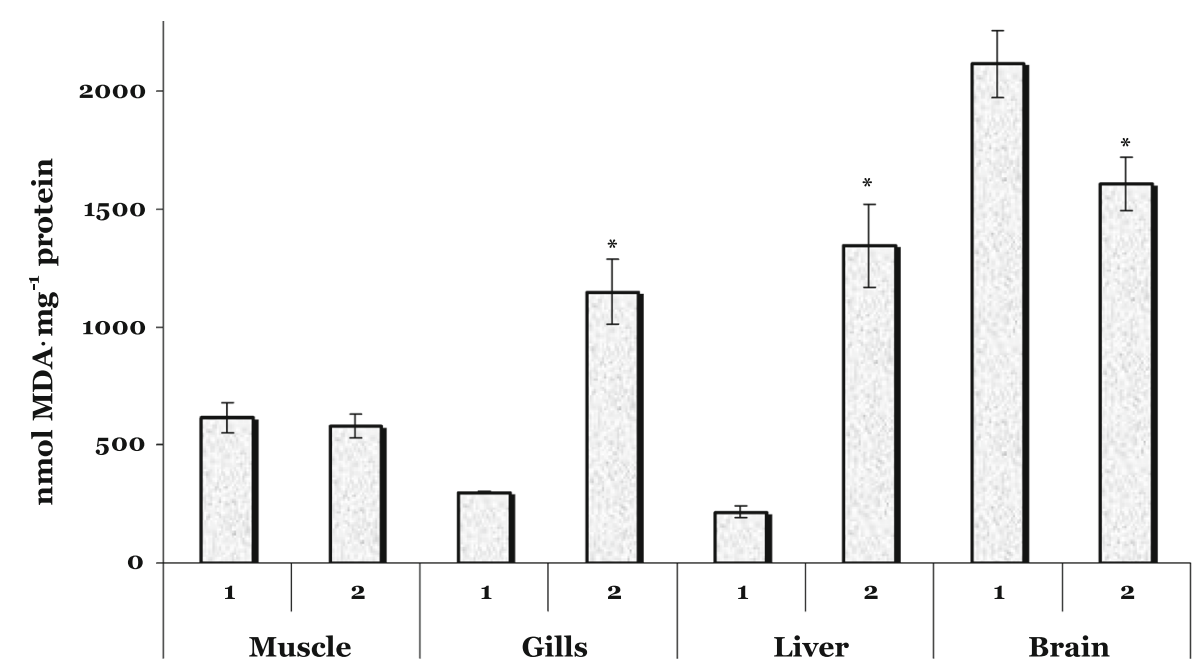

Fig. 1 The level of lipid peroxidation (nmol MDA per mg protein) in the muscle, gills, liver, and brain of the trout treated by vaccine against furunculosis. 1 unhandled controls, 2 trout treated by vaccine against furunculosis. Data are represented as mean \pm SEM $(n=15)$. Asterisk Significant difference was shown as $p<0.05$ when the vaccinated group and unhandled group values were compared 

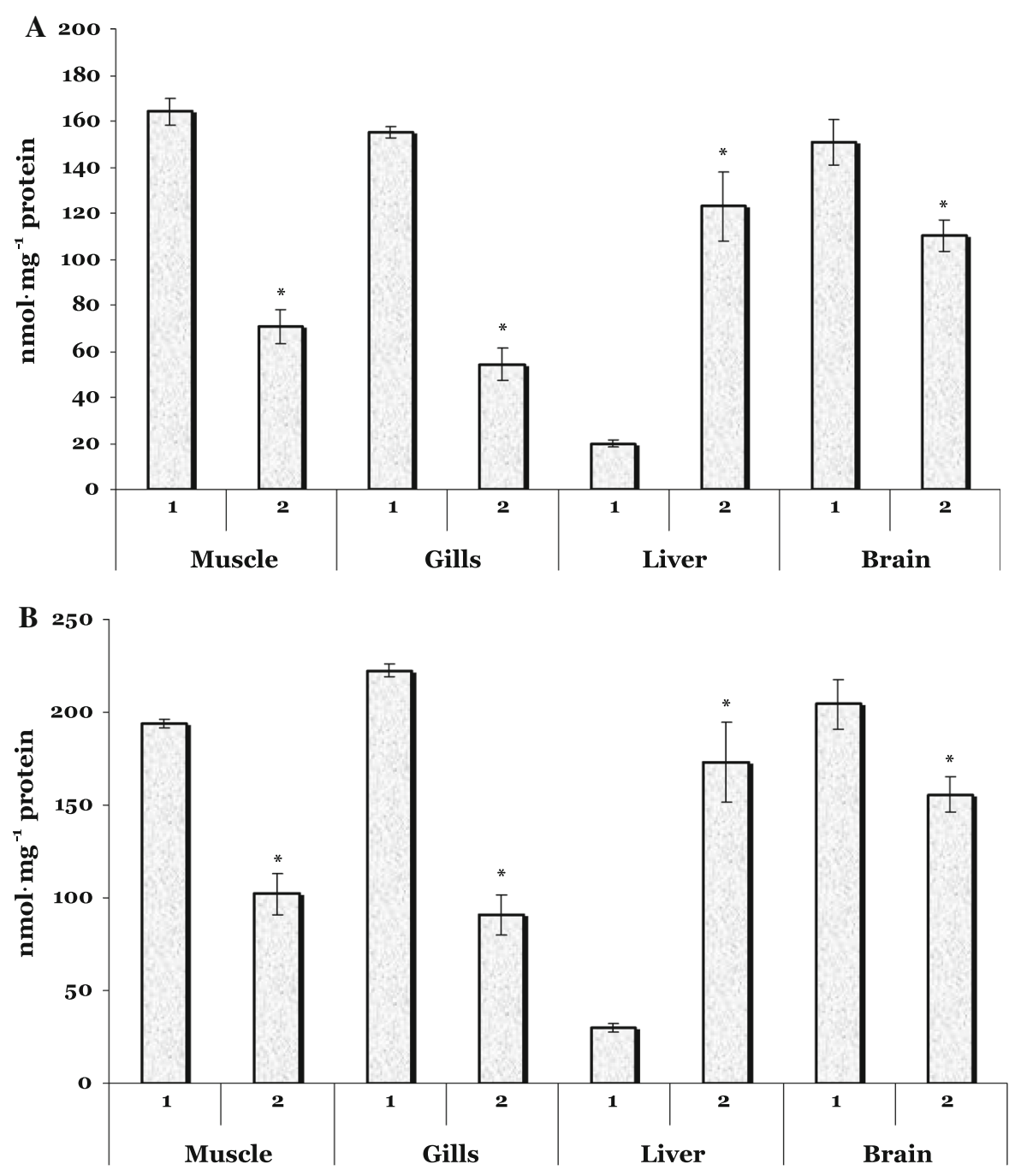

Fig. 2 Aldehyde (a) and ketonic derivates (b) of carbonyl content in the muscle, gills, liver, and brain of the trout vaccinated against furunculosis. 1 unhandled controls, 2 trout treated by vaccine against furunculosis. Data are represented as mean \pm SEM $(n=15)$. Asterisk Significant difference was shown as $p<0.05$ when the vaccinated group and unhandled group values were compared

oxygen species (ROS), or both, which may lead to a series of biochemical and physiological changes, thus, altering normal body homeostasis and tissue injury (Halliwell 1994). Despite the potential danger of the ROS, cells have a variety of defense mechanisms to neutralize the harmful effects of free radicals (Ural 2013).

The present study established that the gills and liver of fish vaccinated against furunculosis have higher level of lipid peroxidation. Skin, gills, and gut are the mucosal tissues associated with the immune system of 
fish (Kirron 2012). Gills are multifunctional—primarily a respiratory organ, they are also involved in the immune defense through the mucosa-associated lymphoid tissues that harbor macrophages, neutrophils, lymphocytes, and mast cells/eosinophilic granulocytes (Pratap and Wendelaar Bonga 1993; Reite and Evensen 2006). Since the gills are in continuous close contact with the aquatic environment, perhaps the higher level of TBARS in gills is due to their function. Fish gills are particularly sensitive to water quality, constituting the first target of pollutants, due to their anatomic location, direct contact with the water and quick absorption (Pereira et al. 2013). In our study, higher level of TBARS in the gills of vaccinated fish apparently is caused by close contact of gills tissue with the aquatic environment. They are also involved in the immune defense through the mucosa-associated lymphoid tissues that harbor macrophages, neutrophils, lymphocytes, and mast cells/eosinophilic granulocytes (Kirron 2012). It well-known phagocytic cells, i.e., neutrophils, monocytes, and macrophages, generate ROS during the respiratory burst by membrane-bound NADPH oxidase and play an important role in defense against microorganisms and various exogenous compounds (Rossi 1986; Pietarinen-Runtti et al. 2000).

Liver is a metabolically active organ with a powerful antioxidant potential. Therefore, TBARS level was higher in the liver than in the other tissues. Our study is in agreement with the data of other researches (Velisek et al. 2011). The significant increase of oxidative stress biomarkers level in liver and gills of vaccinated fish may indicate susceptibility of lipid molecules to ROS and demonstrate the extent of oxidative damage under the influence vaccination against furunculosis.

Skugor et al. (2009) used multiple gene expression profiling to outline the mechanisms that determine success of vaccine protection against furunculosis in Atlantic salmon and to search for the correlates of protection. Several genes with known immune functions showed higher expression levels in liver of salmon, including the phosphotyrosine-independent ligand for lymphocyte-specific protein tyrosine kinase Lck SH2 or nucleoporin p62 that regulates activation of nuclear factor kappa light-chain enhancer of activated B cells (NF-kB) by tumor necrosis factor $\alpha$ (TNF $\alpha$ ) (Skugor et al. 2009). Up-regulation of NF-kB and activator protein AP-1 by pathogens and cytokines 


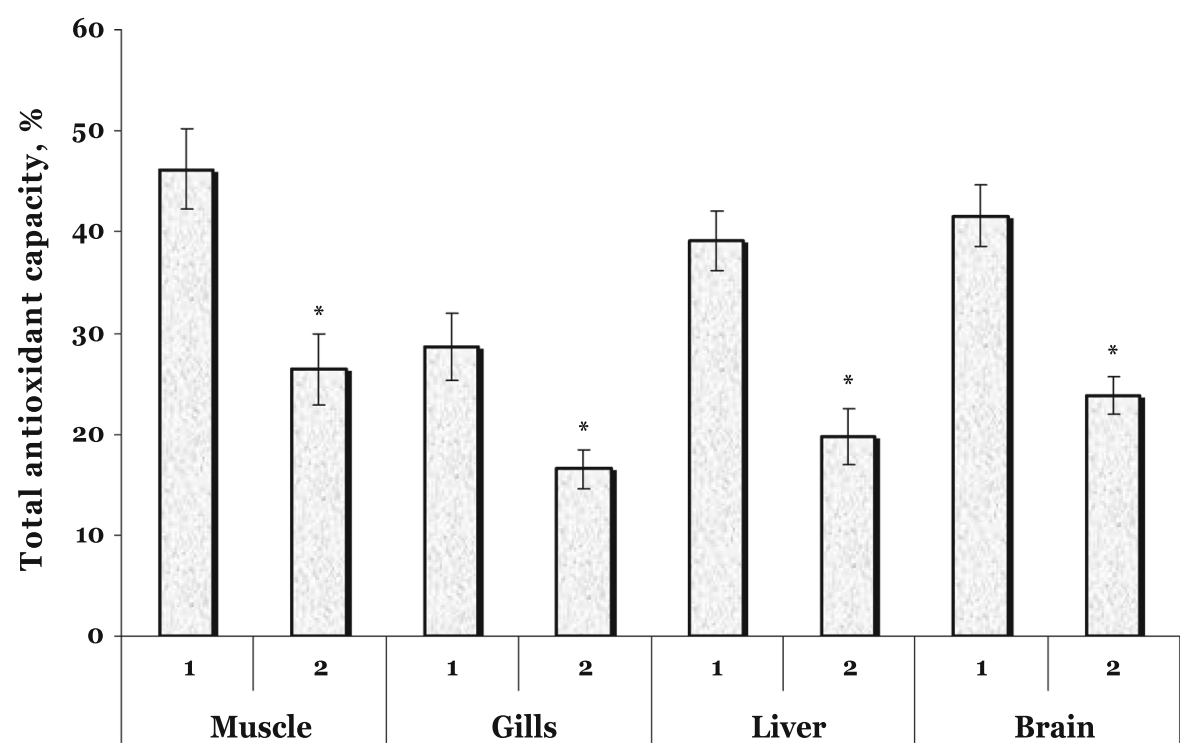

Fig. 3 The total antioxidant capacity in the muscle, gills, liver, and brain of the trout treated by vaccine against furunculosis. 1 unhandled controls, 2 trout treated by vaccine against

induces mass production of immune mediators and effector proteins. NF-kB and Jun proteins respond to various cell-damaging factors, including free radicals and other genotoxic agents that can cause apoptosis, growth arrest, altered DNA repair, or altered differentiation. NF-kB can also activate protection against oxidative and cellular stress by providing anti-apoptotic and proliferation-promoting signals. A suite of chaperones and protein adaptors of different types (heat shock proteins, 14-3-3 proteins, glucose regulated proteins, DnaJ, and cyclophilins) were expressed at higher level in fish with low resistance to furunculosis, and this could be evidence of cellular stress (Skugor et al. 2009). Genes for proteins involved in regulation of redox status and protection against ROS had higher expression levels in vaccinated fish with high resistance to furunculosis (Skugor et al. 2009).

The complement system is the only group of immune genes that showed strong association with survival and can be considered as candidate markers of vaccine protection against furunculosis. The role of complement in antibody-mediated defense against $A$. salmonicida was demonstrated in rainbow trout. The complement system is the major link between the effector anti-bacterial mechanisms of adaptive and innate arms of immunity. The phagocytes of fish play an important role in innate host defense against bacterial infection and participate in various furunculosis. Data are represented as mean $\pm \operatorname{SEM}(n=15)$. Asterisk Significant difference was shown as $p<0.05$ when the vaccinated group and unhandled group values were compared

immunoregulatory processes (Skugor et al. 2009). Nikoskelainen et al. (2005) investigated the effects of various opsonins in the ingestion and adhesion processes by examining respiratory burst activity in blood and head kidney fish phagocytes. Combination of specific IgM and complement accelerated ingestion of target bacteria and ingestion-activated respiratory burst in phagocytes (Nikoskelainen et al. 2005). The antibody-mediated opsonophagocytosis was determined as the respiratory burst activity of blood monocytes and granulocytes against bacterial antigens (Nikoskelainen et al. 2007). ROS production is an important effector mechanism mediating intracellular killing of microbes by phagocytes. On the other side, inappropriate or untimely ROS production can lead to tissue damage (Steevels et al. 2013).

The oxidative modification of protein (OMP) could be used as molecular markers of oxidative stress (Levine et al. 1990). Bagnyukova et al. (2006) suggest that most stressful conditions lead to a quick increase in level of oxidatively modified proteins. Thus, OMP levels have risen as a result of other kinds of stressors (Stadtman and Levine 2000). Accumulation of oxidized proteins has also been found during aging and in some disorders (Sohal 2002). ROS can attack multiple cellular constituents, including protein, nucleic acids, and lipids, leading to disruption of cellular function and integrity (Sturve et al. 2008). The formation of 
oxidative-modified protein causing conformational changes, decreased catalytic activity in enzymes and ultimately resulting, owing to increased susceptibility to protease action, in breakdown of proteins by proteases (Almroth et al. 2008). Our results show that the vaccination against furunculosis caused decrease level of oxidative modification of protein in muscles, gills, and brain of vaccinated fish as compared with the control-unhandled group. On the contrary, level of oxidative modification of protein was higher in liver of vaccinated fish as compared with the other tissues. This is obviously related to the functional activity of liver. The liver plays a key role in most metabolic processes, especially detoxification and, consequently, in the formation of ROS.

ROS in cells may lead to an elevation of antioxidant enzymes as a defense mechanism (Velisek et al. 2011). Antioxidants provide cells with a comprehensive defense from ROS-induced damage. These defenses include low molecular weight compounds (e.g., glutathione and ascorbate) and antioxidant enzymes (e.g., superoxide dismutase, catalase, and glutathione-dependent antioxidant enzymes) (Grim et al. 2013). Glutathione (GSH), a tri-peptide that can neutralize ROS, also serves as a critical cofactor for several glutathione-dependent antioxidant enzymes (Pacitti et al. 2013). The first line of defense against oxidative stress consists of the antioxidant enzymes SOD, CAT, and GPx, which converts superoxide radicals into hydrogen peroxide and then into water and molecular oxygen (Ural 2013). Induction of antioxidant enzymes is an important line of defense against oxidative stress in fish (Velisek et al. 2011). SOD is a group of metalloenzymes that catalyzes the dismutation of superoxide to hydrogen peroxide, plays a crucial antioxidant role and constitutes the primary defense against the toxic effects of superoxide radicals in aerobic organisms (Cheeseman and Slater 1992). In our study, significant increase in SOD activity was observed in muscles and liver of vaccinated trout. It could be adaptive response to the immunization that neutralizes the impact of ROS and may be of importance in preventing membrane lipid peroxidation when the latter is initiated by a combination of $\mathrm{Fe}^{3+}$ and $\mathrm{O}_{2}^{-\bullet}$-generating system (Cadenas et al. 1992). A similar result of increased SOD activity has been reported in carp tissues following xenobiotics exposure (Ural 2013; Oruç 2010).
CAT, associated with other enzymatic antioxidants (peroxidases, SOD), is capable of removing, neutralizing, or scavenging ROS and is, with the GSH redox cycle, the primary cellular enzymatic defense system against hydrogen peroxide, that it converts to $\mathrm{H}_{2} \mathrm{O}$ and $\mathrm{O}_{2}$ (Dorval and Hontela 2003). The decreased CAT activities indicate the reduced capacity to scavenge hydrogen peroxide produced in muscles and gills of vaccinated trout in response to oxidative stress. Similarly, the inhibition of the CAT activity by pesticides has been reported in various studies in fish species (Ural 2013). For example, Oruç and Usta (2007) reported that diazinon caused a decrease in the CAT activity in the muscle of Cyprinus carpio. Similarly, influence of chlorpyrifos significantly decreased CAT activities in the liver, kidney, and gills of Cyprinus carpio (Ural 2013). In our study, the CAT activity was also significantly decreased in the muscles and gills of vaccinated trout. The decrease in the CAT activity observed in the tissues could be due to the production of superoxide radicals under the vaccination. At that time, superoxide radicals can inhibit CAT activity (Kono and Fridovich 1982).

The most important antioxidant enzymes linked with antioxidant defenses against oxidative stress are glutathione peroxidase, reductase, and transferase (Hayes and McLellan 1999). The activity of antioxidant enzymes, such as GPx and other markers of oxidative stress, has been extensively used in fish both in vivo and in vitro studies (Dörr et al. 2008; Misra and Niyogi 2009; Misra et al. 2012).

GR plays an important role in cellular antioxidant protection and adjustment processes of metabolic pathways (Cazenave et al. 2006). It catalyzes the reduction of glutathione disulfide to reduced glutathione in an NADPH-dependent reaction. In our study, GR activity was significantly decreased in the muscles and gills of vaccinated trout, but increased in the liver, probably due to an availability of NADPH in different tissues.

Inactivation of lipid-derived hydroperoxides can be catalyzed by GSH-dependent selenoperoxidases or certain non-seleno-GSH-S-transferases. Two selenoperoxidases are known to exist in cells: classical GSHperoxidase (GPx), which acts on relatively polar substrates, e.g., $\mathrm{H}_{2} \mathrm{O}_{2}$ or fatty acid hydroperoxides, and phospholipid hydroperoxide GSH-peroxidase (Ursini and Bindoli 1987). GPx is dependent on access to glutathione disulfide by the NADPH- 
dependent GR. Decrease in glutathione-mediated antioxidant defense system results in oxidative stress and increased cytotoxicity, whereas elevation of intracellular GSH levels is recognized as an adaptive response to oxidative stress (Sagara et al. 1998). In our study, the activities of GPx, as well as GR were significantly decreased in the muscles and gills of vaccinated trout.

Total antioxidant capacity in muscles, liver, gills, and brain of vaccinated trout was significantly decreased when compared with the unhandled group. Impairment in the synthesis of enzymatic and nonenzymatic antioxidant of vaccinated fish may be the most important factor in reducing levels of cellular total antioxidant. Similar result was obtained by Banaee et al. (2013). The results showed that diazinon, which is widely used as insecticide, altered the activity of antioxidant enzymes and decreased the TAC-inducing oxidative stress and cellular damage in hepatocytes of rainbow trout (Banaee et al. 2013).

Our results suggest that both the glutathionemediated antioxidant defense system and endogenous CAT play a critical role in intracellular antioxidant defense in vaccinated fishes. At the same time, the antioxidant defenses was significant higher in liver of vaccinated fishes, probably due to a functional activity of liver. The importance of the glutathione-mediated antioxidant defense system in protection against endosulfan-induced oxidative stress was also demonstrated in adrenocortical cells of rainbow trout (Dorval and Hontela 2003).

Oxidative stress biomarkers analyses revealed significant differences between vaccinated fish against furunculosis. We noted strong association between oxidative stress and tissues responses. The liver tissue of vaccinated fish showed higher levels of lipid and protein oxidation biomarkers. Rainbow trout muscle, gills, liver, and brain tissue showed different antioxidant defense responses, likely related to tissuespecific functions. Furthermore, changes in lipid and protein oxidation of vaccinated trout were also tissuedependent. Muscle, gill, and brain tissues had lower level of aldehyde and ketonic derivates of oxidatively modified protein, while liver tissue became more susceptible to oxidative damage induced by vaccination. Muscle and gill glutathione-dependent enzymes activity decreased in vaccinated trout. In contrast, antioxidant defenses in liver tissue increased, which indicate a different response of tissue to vaccination.
Our data suggest that vaccination against furunculosis induced oxidative stress in gill and liver tissues. However, muscle and brain tissue are capable of restoring its pro- and antioxidant balance after vaccination.

Acknowledgments This study was carried out during Anastasiia Andriichuk Scholarship Program (N51200912) supported by The International Visegrad Fund in the Department of Animal Physiology, Institute of Biology and Environmental Protection, Pomeranian University (Slupsk, Poland). We thank The International Visegrad Fund for the support of our study. This work was also supported by grant of the Pomeranian University for Young Scientists.

Open Access This article is distributed under the terms of the Creative Commons Attribution License which permits any use, distribution, and reproduction in any medium, provided the original author(s) and the source are credited.

\section{References}

Almroth BC, Sturve J, Stephensen E, Holth TF, Förlin L (2008) Protein carbonyls and antioxidant defenses in corkwing wrasse (Symphodus melops) from a heavy metal polluted and a PAH polluted site. Mar Environ Res 66(2):271-277

Andrews SR, Sahu NP, Pal AK, Mukherjee SC, Kumar S (2011) Yeast extract, brewer's yeast and spirulina in diets for Labeo rohita fingerlings affect haemato-immunological responses and survival following Aeromonas hydrophila challenge. Res Vet Sci 91(1):103-109

Azad IS, Shankar KM, Mohan CV, Kalita B (2000) Uptake and processing of biofilm and free-cell vaccines of Aeromonas hydrophila in indian major carps and common carp following oral vaccination antigen localization by a monoclonal antibody. Dis Aquat Organ 43(2):103-108

Bagnyukova TV, Chahrak OI, Lushchak VI (2006) Coordinated response of goldfish antioxidant defenses to environmental stress. Aquat Toxicol 78(4):325-331

Banaee M, Sureda A, Mirvaghefi AR, Ahmadi K (2013) Biochemical and histological changes in the liver tissue of rainbow trout (Oncorhynchus mykiss) exposed to sublethal concentrations of diazinon. Fish Physiol Biochem 39(3):489-501

Bradford MM (1976) A rapid and sensitive method for the quantitation of microgram quantities of protein utilizing the principle of protein-dye binding. Anal Biochem 72:248-254

Bricknell I, Dalmo RA (2005) The use of immunostimulants in fish larval aquaculture. Fish Shellfish Immunol 19(5):457-472

Cadenas E, Hochstein P, Ernster L (1992) Pro- and antioxidant functions of quinones and quinone reductases in mammalian cells. Adv Enzymol Relat Areas Mol Biol 65:97-146

Cazenave J, Bistoni Mde L, Pesce SF, Wunderlin DA (2006) Differential detoxification and antioxidant response in 
diverse organs of Corydoras paleatus experimentally exposed to microcystin-RR. Aquat Toxicol 76(1):1-12

Cheeseman KH, Slater JF (1992) An introduction to free radical biochemistry. In: Cheeseman KH, Slater TS (eds) Free radicals in medicine. Churchill Livingstone, New York, pp 481-493

Dörr AJ, Pacini N, Abete MC, Prearo M, Elia AC (2008) Effects of a selenium-enriched diet on antioxidant response in adult crayfish (Procambarus clarkii). Chemosphere 73(7):1090-1095

Dorval J, Hontela A (2003) Role of glutathione redox cycle and catalase in defense against oxidative stress induced by endosulfan in adrenocortical cells of rainbow trout ( $\mathrm{On}$ corhynchus mykiss). Toxicol Appl Pharmacol 192(2): 191-200

Dubinina EE, Burmistrov SO, Khodov DA, Porotov IG (1995) Oxidative modification of human serum proteins. A method of determining it. Vopr Med Khim 41(1):24-26 Article in Russian, Abstract in English

Galaktionova LP, Molchanov AV, El'chaninova SA, Varshavskiř B (1998) Lipid peroxidation in patients with gastric and duodenal peptic ulcers. Klin Lab Diagn 6:10-14 Article in Russian, Abstract in English

Glatzle D, Vuilleumier JP, Weber F, Decker K (1974) Glutathione reductase test with whole blood, a convenient procedure for the assessment of the riboflavin status in humans. Experientia 30(6):665-667

Grim JM, Simonik EA, Semones MC, Kuhn DE, Crockett EL (2013) The glutathione-dependent system of antioxidant defense is not modulated by temperature acclimation in muscle tissues from striped bass, Morone saxatilis. Comp Biochem Physiol A Mol Integr Physiol 164(2):383-390

Halliwell B (1994) Free radicals, antioxidants, and human disease: curiosity, cause, or consequence? Lancet 344(8924):721-724

Harikrishnan R, Balasundaram C, Heo MS (2010) Herbal supplementation diets on hematology and innate immunity in goldfish against Aeromonas hydrophila. Fish Shellfish Immunol 28(2):354-361

Hayes JD, McLellan LI (1999) Glutathione and glutathionedependent enzymes represent a coordinately regulated defence against oxidative stress. Free Radic Res 31(4):273-300

Kamyshnikov VS (2004) Reference book on clinic and biochemical researches and laboratory diagnostics. MEDpress-inform, Moscow (In Russian)

Karunasagar I, Ali A, Otta SK, Karunasagar I (1997) Immunization with bacterial antigens: infections with motile aeromonads. Dev Biol Stand 90:135-141

Kirron V (2012) Fish immune system and its nutritional modulation for preventive health care. An Feed Sci Tech 173:111-133

Kono Y, Fridovich I (1982) Superoxide radical inhibits catalase. J Biol Chem 257(10):5751-5754

Koroliuk MA, Ivanova LI, Maǐorova IG, Tokarev VE (1988) A method of determining catalase activity. Lab Delo 1:16-19 Article in Russian, Abstract in English

Kostiuk VA, Potapovich AI, Kovaleva ZhV (1990) A simple and sensitive method of determination of superoxide dismutase activity based on the reaction of quercetin oxidation. Vopr Med Khim 36(2):88-91 Article in Russian, Abstract in English

Larsen JL, Pedersen K (1997) Vaccination strategies in freshwater salmonid aquaculture. Dev Biol Stand 90:391-400

Levine RL, Garland D, Oliver CN, Amici A, Climent I, Lenz AG, Ahn BW, Shaltiel S, Stadtman ER (1990) Determination of carbonyl content in oxidatively modified proteins. Methods Enzymol 186:464-478

Lillehaug A (1997) Vaccination strategies in seawater cage culture of salmonids. Dev Biol Stand 90:401-408

Loghothetis PN, Austin B (1994) Immune response of rainbow trout (Oncorhynchus mykiss, Walbaum) to Aeromonas hydrophila. Fish Shellfish Immunol 4:239-254

Misra S, Niyogi S (2009) Selenite causes cytotoxicity in rainbow trout (Oncorhynchus mykiss) hepatocytes by inducing oxidative stress. Toxicol In Vitro 23(7):1249-1258

Misra S, Hamilton C, Niyogi S (2012) Induction of oxidative stress by selenomethionine in isolated hepatocytes of rainbow trout (Oncorhynchus mykiss). Toxicol In Vitro 26(4):621-629

Moin VM (1986) A simple and specific method for determining glutathione peroxidase activity in erythrocytes. Lab Delo 12:724-727 Article in Russian, Abstract in English

Nikoskelainen S, Verho S, Airas K, Lilius EM (2005) Adhesion and ingestion activities of fish phagocytes induced by bacterium Aeromonas salmonicida can be distinguished and directly measured from highly diluted whole blood of fish. Dev Comp Immunol 29(6):525-537

Nikoskelainen S, Verho S, Järvinen S, Madetoja J, Wiklund T, Lilius EM (2007) Multiple whole bacterial antigens in polyvalent vaccine may result in inhibition of specific responses in rainbow trout (Oncorhynchus mykiss). Fish Shellfish Immunol 22(3):206-217

Oruç EÖ (2010) Oxidative stress, steroid hormone concentrations and acetylcholinesterase activity in Oreochromis niloticus exposed to chlorpyrifos. Pestic Biochem Physiol 96:160-166

Oruç EÖ, Usta D (2007) Evaluation of oxidative stress responses and neurotoxicity potential of diazinon in different tissues of Cyprinus carpio. Environ Toxicol Pharmacol 23(1):48-55

Pacitti D, Wang T, Page MM, Martin SA, Sweetman J, Feldmann J, Secombes CJ (2013) Characterization of cytosolic glutathione peroxidase and phospholipid-hydroperoxide glutathione peroxidase genes in rainbow trout $(\mathrm{On}$ corhynchus mykiss) and their modulation by in vitro selenium exposure. Aquat Toxicol 130-131:97-111

Pereira S, Pinto AL, Cortes R, Fontaínhas-Fernandes A, Coimbra AM, Monteiro SM (2013) Gill histopathological and oxidative stress evaluation in native fish captured in Portuguese northwestern rivers. Ecotoxicol Environ Saf 90:157-166

Pietarinen-Runtti P, Lakari E, Raivio KO, Kinnula VL (2000) Expression of antioxidant enzymes in human inflammatory cells. Am J Physiol Cell Physiol 278(1):C118-C125

Pratap HB, Wendelaar Bonga SE (1993) Effect of ambient and dietary cadmium on pavement cells, chloride cells, and $\mathrm{Na}+$ / $\mathrm{K}+$-ATPase activity in the gills of the freshwater teleost Oreochromis mossambicus at normal and high calcium levels in the ambient water. Aquat Toxicol 26:133-149 
Press CM, Lillehaug A (1995) Vaccination in European salmonid aquaculture: a review of practices and prospects. $\mathrm{Br}$ Vet J 151(1):45-69

Pryor WA (1986) Oxy-radicals and related species: their formation, lifetimes, and reactions. Annu Rev Physiol 48:657-667

Rahman MH, Kawai K (2000) Outer membrane proteins of Aeromonas hydrophila induce protective immunity in goldfish. Fish Shellfish Immunol 10(4):379-382

Reite OB, Evensen O (2006) Inflammatory cells of teleostean fish: a review focusing on mast cells/eosinophilic granule cells and rodlet cells. Fish Shellfish Immunol 20(2):192208

Rømer Villumsen K, Dalsgaard I, Holten-Andersen L, Raida MK (2012) Potential role of specific antibodies as important vaccine induced protective mechanism against Aeromonas salmonicida in rainbow trout. PLoS ONE 10:e46733

Rossi F (1986) The O2-•-forming NADPH oxidase of phagocytes; nature, mechanisms of activation and function. Biochem Biophys Acta 853:65-89

Sagara Y, Dargusch R, Chambers D, Davis J, Schubert D, Maher P (1998) Cellular mechanisms of resistance to chronic oxidative stress. Free Radic Biol Med 24(9):1375-1389

Siwicki AK, Anderson DP, Rumsey GL (1994) Dietary intake of immunostimulants by rainbow trout affects non-specific immunity and protection against furunculosis. Vet Immunol Immunopathol 41(1-2):125-139

Siwicki AK, Klein P, Morand M, Kiczka W, Studnicka M (1998) Immunostimulatory effects of dimerized lysozyme (KLP-602) on the nonspecific defense mechanisms and protection against furunculosis in salmonids. Vet Immunol Immunopathol 61(2-4):369-378

Siwicki A, Morand M, Kazuń K, Keck N, Gąbski E, Magaczewska J (2002) Application of anti-stress products in aquaculture: influence of propiscin on the effectiveness o fan anti-Yersinia ruckeri vaccine in rainbow trout $O n$ corhynchus mykiss (Wal.). Arch Pol Fish 10(2):143-152

Skugor S, Jørgensen SM, Gjerde B, Krasnov A (2009) Hepatic gene expression profiling reveals protective responses in Atlantic salmon vaccinated against furunculosis. BMC Genom 10:503-518

Sohal RS (2002) Oxidative stress hypothesis of aging. Free Radic Biol Med 33(5):573-574
Sommerset I, Kross $\varnothing y$ B, Biering E, Frost P (2005) Vaccines for fish in aquaculture. Expert Rev Vaccines 4(1):89-101

Stadtman ER, Levine RL (2000) Protein oxidation. Ann NY Acad Sci 899:191-208

Steevels TA, van Avondt K, Westerlaken GH, Stalpers F, Walk J, Bont L, Coffer PJ, Meyaard L (2013) Signal inhibitory receptor on leukocytes-1 (SIRL-1) negatively regulates the oxidative burst in human phagocytes. Eur J Immunol 43(5):1297-1308

Sturve J, Almroth BC, Förlin L (2008) Oxidative stress in rainbow trout (Oncorhynchus mykiss) exposed to sewage treatment plant effluent. Ecotoxicol Environ Saf 70(3):446-452

Swain P, Behera T, Mohapatra D, Nanda PK, Nayak SK, Meher PK, Das BK (2010) Derivation of rough attenuated variants from smooth virulent Aeromonas hydrophila and their immunogenicity in fish. Vaccine 28(29):4626-4631

Ural MȘ (2013) Chlorpyrifos-induced changes in oxidant/antioxidant status and haematological parameters of Cyprinus carpio: ameliorative effect of lycopene. Chemosphere 90(7):2059-2064

Ursini F, Bindoli A (1987) The role of selenium peroxidases in the protection against oxidative damage of membranes. Chem Phys Lipids 44(2-4):255-276

Vanya Ewart K, Williams J, Richards RC, Gallant JW, Melville K, Douglas SE (2008) The early response of Atlantic salmon (Salmo salar) macrophages exposed in vitro to Aeromonas salmonicida cultured in broth and in fish. Dev Comp Immunol 32(4):380-390

Velisek J, Stara A, Li Z-H, Silovska S, Turek J (2011) Comparison of the effects of four anaesthetics on blood biochemical profiles and oxidative stress biomarkers in rainbow trout. Aquaculture 310:369-375

Vivas J, Riaño J, Carracedo B, Razquin BE, López-Fierro P, Naharro G, Villena AJ (2004) The auxotrophic aroA mutant of Aeromonas hydrophila as a live attenuated vaccine against $A$. salmonicida infections in rainbow trout (Oncorhynchus mykiss). Fish Shellfish Immunol 16(2):193-206

Zar JH (1999) Biostatistical Analysis, 4th edn. Prentice Hall Inc., New Jersey 